(RESEARCH ARTICLE)

\title{
Bioconversion of waste paper into soil conditioner and its effect on plants growth and microbial population of the soil
}

\author{
Jones Agnes M, Akpan Patience S and Ibuot Aniefon A* \\ Department of Science Technology, Akwa Ibom State Polytechnic, Ikot Osurua, Ikot Ekpene, Akwa Ibom State, Nigeria.
}

Publication history: Received on 05 July 2020; revised on 18 July 2020; accepted on 21 July 2020

Article DOI: https://doi.org/10.30574/wjarr.2020.7.1.0233

\begin{abstract}
This research work focused on bioconversion of waste paper into soil conditioner and its effect on plants growth and soil microbial population. The effects were studied for 21 days and the number of seeds germinated and their height were measured at 3 days interval. Percentage (\%) seed germination across the samples was $100 \%$. The height of the plants in soil treated with composted waste paper ranged between $80 \pm 0.98 \mathrm{~mm}$ and $643 \pm 1.76 \mathrm{~mm}$ that of control soil ranged between $70 \pm 1.98 \mathrm{~mm}$ and $503 \pm 1.67 \mathrm{~mm}$. The result for the microbial analysis revealed a total bacterial count range from $4.0 \pm 1.01$ to $6.9 \pm 1.03 \times 10^{5} \mathrm{cfu} / \mathrm{g}$ for soil samples treated with composted waste paper and $5.0 \pm 0.78$ to $6.1 \pm 1.29 \times 10^{5} \mathrm{cfu} / \mathrm{g}$ for control. The results also revealed a total of eight bacterial genera and they include; Bacillus sp, Pseudomonas sp, E.coli, Micrcoccus sp, Staphylococuss sp, Proteus sp, Enterobacter sp, Klebsiella sp respectively. Total fungal count ranged from $1.5 \pm 0.97$ to $2.9 \pm 0.92 \times 10^{5} \mathrm{cfu} / \mathrm{g}$ for soil samples treated with composted waste paper. A total of five fungal genera were isolated and they included Aspergillus sp, Penicillium sp, Mucor sp, Rhizopus sp, and Sacharomyces sp respectively. The most prevalent bacterium across the sample was Bacillus sp with $33.33 \%$ while the most prevalent fungus across the sample was Penicillium sp with $41.67 \%$.
\end{abstract}

Keywords: Bioconversion; Waste paper; Soil conditioner; Plants; Microorganisms

\section{Introduction}

In many countries, a large chunk of municipal waste including waste paper is not properly dispose therefore causing a potential environmental threat because of pathogens and toxic pollutants present in the waste [1,2]. Landfill is recently not considered the best as it is problematic and leads to pollution issues such as leachate and landfill gases. Organic municipal waste and other organic materials such as waste paper and manure can be composted and used in improving soil structure and crop performance. Composting therefore is an aerobic process which enables the organic matter to decompose to humic -like substances. The quantity of the material deduces during composting and the resulting compost is very stable and rich in nutrients than the raw material and can improve soil quality and crop productivity and also sustain agricultural production [3]. The high cost of inorganic fertilizers and the potential environmental risk that results by overuse have awaken the interest in using organic matter amendments such as plant residues including waste paper, manures and composts.

However, compost properties differ greatly depending on compost materials and procedure [4]. Effective and optimal use of compost depends on a better understanding of the relationship between the properties of compost and their effect on soil. The use of waste paper as source of plant nutrients and organic matter to ameliorate soil structure is of great interest to maintain soil productiveness $[5,6]$ especially in low carbon input rotation systems.

Enhancement of soil structure and soil carbon content increase after application of waste paper could be dependent on the segment of their organic carbon in the varying and stable carbon pools. Their effects on aggregation of soil and accumulation rate of carbon do not only depend on the quantity but also on the quality of the organic wastes. The rate

\footnotetext{
*Corresponding author: Ibuot Aniefon A; Phone number: +234[0] 8185663414; Email: anialphonsus@yahoo.com
} 
of the decomposition of the organic wastes by soil microbes is connected to the rates at which the organic wastes are decomposed by soil microorganisms and therefore influence their ability to stimulate the soil microflora and produce humic substances $[7,8]$.

Soil aggregation is a result of the product that is formed during decomposition of polysaccharides, humic substances and microbial products along with phenolic $[9,10]$. Waste papers and sludge are lignin-rich organic material known to resist mineralization [11] and therefore adds to increase in the soil organic matter content [12, 8, 13]. A long-lasting effect of waste paper and sludge may be observed on soil structure [14] and fertility compared to some other animal manure which generally induce short-term improvement due to their high mineralization potential as demonstrated by Darwish et al. [15]. This study will therefore bioconvert waste paper into soil conditioner through composting and will determine the effect of the produced soil conditioner on soil microorganisms and plant growth.

\section{Material and methods}

\subsection{Description of study area}

This research study was done at the botanical garden of Akwa Ibom State Polytechnic, Ikot Osurua, Ikot Ekpene, Nigeria. The experiment was done in March 2018 and the work lasted for four months.

\subsection{Sample collection and preparation}

Waste paper was collected around Akwa Ibom State Polytechnic offices and paper waste bins. Maize seeds were purchased from a nearby community market at Ikot Osurua, Ikot Ekpene in Akwa Ibom State, Nigeria.The waste paper and the maize seeds were taken to the botanical garden of Akwa Ibom State Polytechnic for studies.

\subsection{Waste paper composting}

Wastepaper was grinded using a grinder. The grinded waste paper was kept and allowed to decompose. Water was sprinkled on the compost heap at 4 days interval to aid decomposition and the temperature of the windrows and the atmosphere was taken. Microbiological analysis of the windrows was carried out at weekly intervals. The composting process was allowed for 21 days.

\subsection{Microbiological analysis}

Samples of the composted paper were taken at weekly intervals and analyzed for total bacterial count (TBC) and total fungi count (TFC). Serial dilution of the composted waste paper was carried out, $1 \mathrm{~mL}$ inoculums of a known dilution factor was inoculated in a prepared nutrient agar and sabouraud dextrose agar (SDA) for bacterial and fungal growth respectively. The prepared plates were incubated at $37^{\circ} \mathrm{C}$ in the incubator for $24 \mathrm{hrs}$ in the case of bacterial culture and fungal culture was incubated in room temperature for 4 to 5 days. After incubation, bacterial isolates were characterized using cultural, morphological and biochemical characterization which include Gram-stain, catalase test, methyl red test, indole test, urea test, spore stain, motility test, coagulase test and sugar fermentation test. Isolates were identified according to the method of Cheesbrough [16]. Fungal isolates were characterize and identified using their macromorphological, microscopic examination in lacto-phenol cotton blue stain for viewing hyphae, reproductive structures, filaments, spores head etc

\subsection{Determination of the effect of composted waste paper on plant growth}

After the composting process had ended, the composted waste paper was weighed out into four portions of $600 \mathrm{~g}$, 400 g, $200 \mathrm{~g}$ and $100 \mathrm{~g}$ respectively. $1 \mathrm{Kg}$ of soil sample was added to each portion. The fifth portion was made to serve as control (1 Kg of soil not treated with the paper waste). Each treatment was filled into a polythene bag; polythene bags were perforated before filling with the treated soil samples and four seeds of maize were planted on each of the treated soil in the polythene bags. The treatments were kept in the botanical garden and were watered at three days interval.

\subsection{Seed germination studies}

Germination studies of the maize seeds were carried out at day 4 to determine the number of seeds that have germinated using the, method of Jinadasa et al [17] and Ibuot et al [18]. Plant height was determined at 4 days interval. 


\subsection{Determination of plant growth}

Plant growth was determined by measuring plant height with use of a meter rule and the number of leaves was counted at 4 days interval using the method of Ibuot et al [19].

\section{Results and discussion}

\subsection{Total bacterial count of waste paper compost}

Total bacterial count of composted paper waste amended soil showed high bacterial count compared to the soil not amended with composted waste paper (control) (Table 1).

Table 1 Total Bacterial count (cfu/g) of composted waste paper with soil

\begin{tabular}{|l|l|l|l|l|l|}
\hline $\begin{array}{l}\text { Sample } \\
\text { Duration }\end{array}$ & \multicolumn{5}{|c|}{ Sample treated/ Bacterial count ( $11^{5}$ CFU/g) } \\
\hline & S1kg+ PW 600g & S1kg+ PW 400g & S1kg+ PW 200g & S1 kg+ PW 100g & S1kg+ PW 0g \\
\hline Day 1 & $5.9 \pm 1.23$ & $4.0 \pm 1.01$ & $4.7 \pm 0.98$ & $5.0 \pm 1.09$ & $5.0 \pm 0.78$ \\
\hline Day 7 & $11.8 \pm 0.87$ & $99.0 \pm 1.78$ & $76.0 \pm 1.09$ & $69.0 \pm 1.03$ & $61.0 \pm 1.29$ \\
\hline Day 14 & $13.3 \pm 1.24$ & $11.9 \pm 1.09$ & $11.5 \pm 1.01$ & $11.5 \pm 1.01$ & $11.3 \pm 1.35$ \\
\hline Day 21 & $14.1 \pm 2.01$ & $12.5 \pm 1.01$ & $12.3 \pm 1.07$ & $12.3 \pm 1.10$ & $11.5 \pm 1.07$ \\
\hline
\end{tabular}

Key: S- soil, PW - Waste paper

\subsection{Bacterial percentage frequency of occurrence in soil amended with waste paper compost}

Bacterial percentage frequency of soil amended with waster paper compost showed Bacillus sp and Pseudomonas sp with highest frequency of occurrence $33.33 \%$ and $26.67 \%$ respectively (Table 2).

Table 2 Percentage occurrence of bacterial isolates of composted waste paper with soil sample

\begin{tabular}{|c|c|c|c|c|c|}
\hline \multicolumn{6}{|c|}{ Sample treated } \\
\hline Isolates & S1kg+ PW 600g & S1kg+ PW 400g & S1kg+ PW 200g & S1kg+ PW 100g & S1kg+ PW 0g \\
\hline Bacillus sp & 29.27 & 10 & 29.09 & 17.39 & 33.33 \\
\hline E. coli & 17.07 & 12 & 8.70 & 26.09 & 6.67 \\
\hline Klebsiella sp & 24.39 & 20 & 13.04 & 13.04 & 0 \\
\hline Micrococcus sp & 9.76 & 8 & 17.39 & 4.35 & 20.0 \\
\hline Proteus sp & 2.44 & 8 & 8.70 & 8.70 & 0 \\
\hline $\begin{array}{l}\text { Staphylococcus } \\
\text { sp }\end{array}$ & 4.49 & 12 & 13.04 & 17.39 & 13.33 \\
\hline Pseudomonas sp & 7.73 & 16 & 4.35 & 13.04 & 26.67 \\
\hline Enterobacter sp & 4.49 & 4 & 8.70 & 0 & 0 \\
\hline
\end{tabular}

Key: S- soil, PW - Waste paper

\subsection{Total fungal count of waste paper compost}

Total fungal count of composted paper waste amended soil showed high fungal count compared to the soil not amended with composted waste paper (control) (Table 3) 
Table 3 Total fungal count (CFU/g) of composted waste paper with soil

\begin{tabular}{|l|l|l|l|l|l|}
\hline $\begin{array}{l}\text { Sample } \\
\text { duration }\end{array}$ & \multicolumn{5}{|c|}{ Sample treated / fungal count (x105CFU/g) } \\
\hline & S1kg+ PW 600g & S1kg+ PW 400g & S1kg+ PW 200g & S1kg+ PW 100g & S1kg+ PW 0g \\
\hline Day 1 & $2.0 \pm 1.34$ & $1.5 \pm 0.97$ & $2.0 \pm 0.98$ & $1.9 \pm 1.09$ & $1.8 \pm 1.43$ \\
\hline Day 7 & $2.3 \pm 0.98$ & $1.7 \pm 0.09$ & $1.90 \pm 0.95$ & $1.7 \pm 0.91$ & $1.7 \pm 1.08$ \\
\hline Day 14 & $2.9 \pm 0.92$ & $2.6 \pm 1.06$ & $1.90 \pm 1.02$ & $1.9 \pm 0.08$ & $1.9 \pm 0.98$ \\
\hline Day 21 & $2.6 \pm 1.10$ & $2.9 \pm 1.03$ & $2.7 \pm 0.78$ & $2.2 \pm 0.09$ & $1.8 \pm 0.19$ \\
\hline
\end{tabular}

\subsection{Fungal percentage frequency of occurrence in soil amended with waste paper compost}

Fungal percentage frequency of occurrence of soil amended with paper compost showed Penicillium sp with the highest frequency of occurrence of $41.67 \%$ (Table 4).

Table 4 Percentage occurrence of fungal isolates

\begin{tabular}{|l|l|l|l|l|l|}
\hline Isolate & S1 $\mathbf{~ g}+\mathbf{P W 6 0 0} \mathbf{g}$ & $\mathbf{S 1} \mathbf{~ k g + P W 4 0 0} \mathbf{g}$ & $\mathbf{S 1} \mathbf{~ k g + P W 2 0 0} \mathbf{g}$ & $\mathbf{S 1} \mathbf{~ k g + P W 1 0 0} \mathbf{~}$ & $\mathbf{1} \mathbf{~ k g + 0 ~ g}$ \\
\hline Aspergillus sp & 29.17 & 26.32 & 41.18 & 8.33 & 10.0 \\
\hline Penicillium sp & 16.67 & 21.05 & 11.76 & 41.67 & 30.00 \\
\hline Mucor sp & 4.17 & 10.53 & 5.88 & 25.00 & 20.00 \\
\hline Rhizopus sp & 8.33 & 0 & 17.65 & 16.67 & 40.00 \\
\hline Saccharomyces sp & 41.67 & 42.11 & 23.53 & 8.33 & 0 \\
\hline
\end{tabular}

Key: S- Soil, PW- Waste paper

\subsection{Seed germination studies}

Germination studies of seed showed $100 \%$ germination for soil amended with waste paper compost and the control (soil not amended with waste paper compost) (Table 5).

Table 5 Percentage (\%) seed germination of seeds planted on soil treated with composted wastepaper

\begin{tabular}{|l|l|l|l|l|l|}
\hline $\begin{array}{l}\text { Day/ } \\
\text { germinated } \\
\text { seed }\end{array}$ & S1 kg+PW600 g & S1 kg+PW400 g & S1 kg+PW200 g & S1 kg+ PW100 g & $\begin{array}{l}\text { S1 } \\
\text { kg+PW0 }\end{array}$ \\
\hline & 100 & 100 & 100 & 100 & 100 \\
\hline
\end{tabular}

\subsection{Plant height}

Plant height showed soil amended with composted waste paper having highest height compared to soil without composted waste paper (Table 6).

Table 6 Height of seedlings planted in waste paper composted treated soil

\begin{tabular}{|l|l|l|l|l|l|}
\hline Isolate & Seedlings height (mm) / Days \\
\hline & Day 6 & Day 10 & Day 14 & Day 18 & Day 22 \\
\hline S1 kg+PW600 g & $87 \pm 0.67$ & $115 \pm 2.01$ & $284 \pm 2.67$ & $475 \pm 2.11$ & $643 \pm 1.76$ \\
\hline S1 kg+ PW400 g & $80 \pm 0.89$ & $121 \pm 1.88$ & $258 \pm 1.98$ & $453 \pm 1.70$ & $606 \pm 0.98$ \\
\hline S1 kg+PW200 g & $83 \pm 1.09$ & $135 \pm 1.19$ & $221 \pm 0.67$ & $386 \pm 0.94$ & $547 \pm 1.70$ \\
\hline S1 kg+ PW100 g & $80 \pm 0.98$ & $112 \pm 1.91$ & $220 \pm 1.19$ & $369 \pm 1.28$ & $518 \pm 1.02$ \\
\hline S1 kg+PW0 g & $70 \pm 1.98$ & $170 \pm 0.95$ & $216 \pm 1.10$ & $354 \pm 1.36$ & $503 \pm 1.67$ \\
\hline
\end{tabular}




\section{Discussion}

Compost production is considered an economic and environmentally friendly means to reduce the waste going into landfill. Compost application can improve soil quality and productiveness as well as maintaining of agricultural production by improving soil organic matter and supplying nutrients. Organic matter is a vital component of a healthy soil as it plays important role in soil physical, chemical and biological fertility. On the contrary, compost application can also exert some adverse effect on the soil fertility as well as microbial population thus, the aim of the present study.

In the present study, the results obtained revealed that waste paper had some effect on the soil fertility and microbial population as well compared to soil not amended with waste paper compost. The effect exerted by this composted waste paper was seen to change overtime with respect to the concentration of the waste paper in an environment. The results showed that seed were able to germinate $100 \%$ on both soils amended with composted waste paper and the control (soil not amended with composted waste paper). The germination of the seeds on day four [4] indicates the metabolic process exerted by some organisms through the secretion of enzymes to decomposed the waste to produced requirement necessary for growth [3]

The results obtained from microbiological assessment revealed a total of eight bacterial genera which include Bacillus sp, E. coli, Klebsiella sp, Micrococcus sp, Proteus sp, Staphylococcus sp, Pseudomonas sp and Enterobacter sp while a total six fungal genera were isolated which were; Aspergillus sp, Penicillium sp, Mucor sp, Rhizopus sp and Saccharomyces sp . The results obtained agree with the work of who reported Okoh et al., [20] that compost genera increase the abundance of soil microorganisms. The predominant occurrence of Bacillus sp across the sample also agrees with the work of Bossio et al [21] who reported that addition of compost from various sources has been shown to increase the abundance of gram positive bacteria. The presence of Staphylococcus sp was not a surprise as though this is not a bacterium found in the soil could be associated with the waste paper as a result of contact with human hands. Micrococcus sp and Pseudomonas sp have been reported as soil bacteria [18, 19, 22, 23].The results obtained also showed that the presence of these pathogens in the soil could in turn affect the soil fertility by reducing plant nutrient uptake which in turn will affect plant growth. The increase in the microbial population with time agrees with the work of Lozana et al.,[24] who reported that changes in microbial activity and community structure after compost application can lead to the increased of soil -borne plant pathogens. The presence of these fungal isolates in the soil samples was not a surprise as there are all soil fungi [25].

The result of the germination study of seeds planted in soil treated with composted waste paper showed $100 \%$ germination for all seeds planted in the different soils treated with the sample which agrees with the work of Lin et al., [26].

The plant, Zea mays showed high growth in soils amended with composted waste paper as determined by plant heights and number of leaves compared to the one planted in soil not amended with composted waste paper. Soils amended with organic matter generally have shown to contribute to carbon accumulation and a subsequent improvement of soil fertility and structure, as reported by Darwish et al. [15] and Varvel [27]. The presence of organic manure in the soil is reported to have positive effects on the soil parameters. Sanchez et al., [4] reported that the presence of organic matter in the soil increases soil $\mathrm{pH}$. It is also reported that it replenishes the soil with essential elements and add humus to the soil. This gives enabling environment for increase in microbial growth and plant performance [28].

\section{Conclusion}

Waste paper management is a major challenge in densely populated areas like educational institutions, secretariats, hospitals etc. In most cases waste papers are disposed into gutters where they cause blockage and water flood during rainy season. Disposal of waste paper with other waste would lead resources waste that could be converted and reused as soil conditioners. In this study, soil amended with composted waste paper has shown to improve plant growth and performance. This clearly shows that waste paper could be composted and used as soil conditioner.

\section{Compliance with ethical standards}

\section{Acknowledgments}

The article was sponsored by TETFund research grant, Nigeria. 


\section{Disclosure of conflict of interest}

The authors declare no conflict of interest.

\section{References}

[1] Darvy HM, Stone AG and Dick RP. (2006). Compost and manure mediated impacts on soil borne pathogens and soil quality. Soil Science Society of America Journal, 70, 347-358.

[2] De Arauja AS, De Melo WJ and Singh RP. (2009). Municipal solid waste compost amendment in agricultural soil: Changes in soil microbial biomass. Review in Environmental Science and Biotechnology, 7, 1-9.

[3] Barral MT, Paradelo R, Moldes AB, Dominquez M and Diaz-Fierros F. (2009). Utilization of MSW compsot for organic matter conversion in agricultural soils of NW Spain. Resources Conservation and Recycling, 53, 529-534.

[4] Bernal MP, Alburquerque JA and Moral R. (2009). Composting of animal manures and chemical criteria for compost maturity assessment. A review. Bioresource Technology, 100, 5444-5453.

[5] Foley BJ and Cooperband LR. (2002). Paper mill residuals and compost effects on soil carbon and physical properties. Journal of Environmental Quality, 13(6), 2086-2095.

[6] N'Dayegamiye A. (2006). Mixed paper mill sludge effects on corn yield nitrogen efficiency and soil properties. Agronomy Journal, 98(6), 1471-1478.

[7] Cheshire MV and Chapman SJ. (1996). Influence of the N and P status of plant material and of added N and P on the mineralization of C from 14C-labelled ryegrass in soil. Biology and Fertility of Soils, 21(3), 166-170.

[8] Lupwayi NZ, Clayton GW, O'Donovan JT, Harker KN, Turkington TK and Rice WA. (2004). Decomposition of crop residues under conventional and zero tillage. Canadian Journal of Soil Science, 84(4), 403-410.

[9] Chantigny MH, Angers DA, Pr'evost D, V'ezina LP and Chalifour FP. (1997). Soil aggregation and fungal and bacterial biomass under annual and perennial cropping systems. Soil Science Society of America Journal, 61(1), 262-267.

[10] Bipfubusa M, Angers DA, N’Dayegamiye A and Antoun H. (2008). Soil aggregation and biochemical properties following the application of fresh and composted organic amendments. Soil Science Society of America Journal, 72(1), 160-166.

[11] Nduwamungu C, Parent LE, Fortin J and Khiari L. (2007). Relationship between biological stability and net N mineralization of organic amendments and fertilizers. in Proceedings of International Conferences on Moving Forward Wasterwater Biosolids Sustainability: Technical, Managerial, and Public Synergy, 439-445.

[12] N'Dayegamiye A. (2009). Soil properties and crop yields in response to mixed paper mill sludges, dairy cattle manure, and inorganic fertilizer application. Agronomy Journal, 101(4), 826- 835.

[13] Six J, Conant RT, Paul EA and Paustian K. (2002). Stabilization mechanisms of soil organic matter: implications for C saturation of soils. Plant and Soil, 241(2), 155-176.

[14] Grandya AS, Porter GA and Erichb MS. (2002). Organic amendment and rotation crop effects on the recovery of soil organic matter and aggregation in potato cropping systems. Soil Science Society of America Journal, 66(4), 1311- 1319.

[15] Darwish OH, Persaud N and Martens DC. (1995). Effect of longterm application of animal manure on physical properties of three soils. Plant and Soil, 176(2), 289-295.

[16] Cheesbrough M. (2006). District laboratory practice in tropical countries (part2) Cambridge University Press, Cambridge, UK, 64-70.

[17] Jinadasa KBPN, Milham PJ, Hawkins CA, Cornish PS, Williams PA, Kaldor CJ and Conroy JP. Survey of cadmium levels in vegetables and soils of greater Sydney. Australia J. Environ. Qual, 26, 924-933.

[18] Ibuot AA, James II, Akpan PS, Ben MG, Etuk CU and Umoren EA. (2019). Assessing the effects of some organic manure on microbial profile of the soil and plant growth. Trends in Applied Sc. Res, 14, 186-192.

[19] Ibuot AA, James II, Ben MG, Etuk CU, Jones AM, Umoren EA, Akpan EL and Akapn EN. (2019). Microbiological analysis of top soil and rhizosphere treated with organic manure. Adv. Biosc and Bioeng, 7(2), 27-31. 
[20] Okoh LA, Badejo MA, Nathaniel IT and Tian G. (1999). Studies on the bacteria, fungi, and springtails (Collembola) of an agroforestry arboretum in Nigeria. Pedobio, 43, 18-27.

[21] Bossio DA, Skow KM and Gunapala KJ. (1998). Determinants of soil microbial communities. Effects of agricultural management, season and soil type on phospholipid fatty acid profiles. Microbial Ecol, 36, 1-12.

[22] Dalal RC. (1998). Soil microbial biomass what do numbers really mean? Aust. J. Exp. Agric, 38, $649-665$.

[23] Ibuot AA and Bajhaiya A. (2013). Biodegradation of crude oil sludge using municipal waste as bulking agent. Asian Journal of Biological Sciences, 6(4), 207-213.

[24] Lozano J, Block WJ and Termorshuizen AJ. (2009). Effect of compost particle size on suppression of plant diseases. Environmental Engineering Science, 26, 601- 607.

[25] Oliveria R, Bacchin P, Robertiello A, Oddo N, Degen I and Tonolo A. (2006). Microbial degradation of soil spills enhanced by slow release fertilizer. App. Environ. Microbiol, 31, 629-634.

[26] Lin XJF, Wang RB, Lin CM, He QH Li and Y Li. (2010). Effect of different organic fertilizers on soil microbial biomass and pea nut yield. Proceedings of the $19^{\text {th }}$ world congress of soil science soil solution for a changing world. August 1-6, 2010. Brisbane, Autsralia, 72-75.

[27] Varvel GE. (2006). Soil organic carbon changes in diversified rotations of the Western Corn Belt. Soil Science Society of America Journal, 70(2), 426-433.

[28] Sanchez P, Shepherd KD, Soule M, Place FM and Buresh RJ et al. (1997). Soil fertility replenishment in africa. An investment in natural resource capital. In: Replenishing soil fertility in Africa, buresh, R. J., Sanchez and f Calhoun (Eds.) ASA, CSSA and SSSA, Madison, Wisconsin, USA, 1-46.

\section{How to cite this article}

Jones AM, Akpan PS and Ibuot AA. (2020). Bioconversion of waste paper into soil conditioner and its effect on plants growth and microbial population of the soil. World Journal of Advanced Research and Reviews, 7(1), $227-233$. 